\title{
Penggunaan Model Pembelajaran Jigsaw untuk Meningkatkan Hasil Belajar Matematika
}

\author{
Ekha Frihatinik \\ SD Negeri 2 Sedayu \\ frihatinikekha9@gmail.com
}

\section{Article History}

received 3/12/2020

\begin{abstract}
The purpose of this study was to improve student learning outcomes in learning mathematics through the Jigsaw learning model. This research method is classroom action research using a cycle model. Each cycle consists of 4 stages, namely: planning, implementation, observation, and reflection. This research was conducted in 2 cycles which were divided into 4 meetings. At the end of each cycle, a post test or evaluation will be carried out to determine the level of achievement and completeness of students in learning. In the pre-cycle activities, the number of students whose score is 71 (KKM) is only 30\% then in the first cycle it increases to $70 \%$ and in the second cycle the student learning completeness increased to $90 \%$. Based on these results, it can be concluded that the use of the Jigsaw Learning Model can improve mathematics learning outcomes in fifth grade students of SDN 2 Sedayu.
\end{abstract}

Keywords: jigsaw, learning outcomes, mathematics

\begin{abstract}
Abstrak
Tujuan penelitian ini adalah untuk meningkatkan hasil belajar siswa dalam pembelajaran matematika melalui model pembelajaran Jigsaw. Metode penelitian ini adalah penelitian tindakan kelas dengan menggunakan model siklus. Tiap siklus terdiri dari 4 tahapan, yaitu : perencanaan, pelaksanaan, observasi, dan refleksi. Penelitian ini dilakukan sebanyak 2 siklus yang terbagi menjadi 4 kali pertemuan. Setiap akhir siklus akan dilakukan post test atau evaluasi untuk mengetahui tingkat ketercapaian dan ketuntasan siswa dalam pembelajaran.Pada kegiatan prasiklus menunjukkan jumlah siswa yang nilainya $\geq 71$ (KKM) hanya $30 \%$ kemudian pada siklus I meningkat menjadi $70 \%$ dan pada siklus II ketuntasan belajar siswa meningkat menjadi $90 \%$. Berdasarkan hasil tersebut dapat disimpulkan bahwa penggunaan Model Pembelajaran Jigsaw dapat meningkatkan hasil belajar matematika pada siswa kelas V SDN 2 Sedayu.
\end{abstract}

Kata kunci: jigsaw, hasil belajar, matematika

Social, Humanities, and Education Studies (SHEs): Conference Series p-ISSN 2620-9284 https://jurnal.uns.ac.id/shes 


\section{PENDAHULUAN}

Matematika merupakan salah satu mata pelajaran yang diajarkan di tingkat pendidikan dasar. Muhsetyo (2009:12) berpendapat, "Sebagai pengetahuan matematika mempunyai ciri-ciri khusus antara lain abstrak, deduktif, konsisten, hirarkis, dan logis". Ciri keabstrakan matematika beserta ciri lainnya yang tidak sederhana menyebabkan matematika tidak mudah untuk dipelajari, dan pada akhirnya banyak siswa yang kurang tertarik terhadap matematika. Menurut Ahmad Susanto (2015: 183), matematika merupakan salah satu bidang studi yang ada pada semua jenjang pendidikan, mulai dari tingkat sekolah dasar hingga perguruan tinggi. Pada sumber yang sama, tertera bahwa bidang studi matematika merupakan bidang studi yang berguna dan membantu dalam menyelesaikan berbagai masalah dalam kehidupan seharihariyang berhubungan dengan hitung menghitung atau yang berkaitan dengan urusan angka-angka berbagai masalah, yang memerlukan suatu keterampilan dan kemampuan untuk memecahkannya. Hal inilah yang menjadikan Sebagian besar siswa SDN 2 Sedayu menganggap matematika itu sulit dan ditakuti sehingga menyebabkan hasil belajar siswa pada pelajaran matematika menjadi rendah karena kurang tertariknya siswa pada pelajaran ini. Padahal, matematika merupakan bekal yang sangat diperlukan dalam kehidupan sehari-hari, karena tidak ada sesuatu apapun di dunia ini yang lepas dari matematika. Rendahnya hasil belajar siswa dapat di lihat pada data awal yang telah didapatkan yang berupa nilai ulangan harian yang telah dilakukan pada siswa kelas $\mathrm{V}$ dari 10 siswa kelas $\mathrm{V}$ yang mengikuti ulangan harian hanya 3 siswa yang nilainya dapat memenuhi KKM 71 yang ditentukan, yaitu sekitar $30 \%$. Sementara siswa yang belum tuntas jumlahnya mencapai 7 siswa, yaitu sekitar $70 \%$, kemudian peneliti melakukan refleksi dan diperoleh informasi bahwa penyebab dari sedikitnya jumlah siswa yang nilainya dapat mencapai $\mathrm{KKM}$ adalah dikarenakan pembelajarannya masih menggunakan model pembelajaran yang konvensional. Ujang Sukandi dalam Muhammad kholik (2011), mendefenisikan bahwa pendekatan konvensional ditandai dengan guru mengajar lebih banyak mengajarkan tentang konsep-konsep bukan kompetensi, tujuannya adalah siswa mengetahui sesuatu bukan mampu untuk melakukan sesuatu, dan pada saat proses pembelajaran siswa lebih banyak mendengarkan. Hal ini mengakibatkan pembelajaaran tidak berjalan efektif dan kurang bermakna, sebab model pembelajaran ini hanya mengalirkan pengetahuan dari guru kepada siswa, sehingga mengakibatkan peranan guru menjadi sangat dominan, sedangkan peranan siswa sangat pasif.

Dalam penerapannya Model Pembelajaran Konvensional juga tidak mengenal adanya interaksi, sebab hanya gurulah sumber segala informasi, sedangkan siswa bertugas untuk duduk diam di kursi, mendengarkan penjelasan dari guru, dan kemudian mencatatnya di buku. Model pembelajaran seperti ini tentulah sangat membosankan dan sama sekali tidak menarik bagi siswa. Hal inilah yang akan membuat minat siswa terhadap pembelajaran matematika menurun. Dan jika dibiarkan berlanjut, maka akan menyebabkan merosotnya hasil belajar matematika siswa dan juga dapat berdampak buruk bagi kehidupan sehari-hari siswa. Dalam kehidupan sehari-harinya kelak siswa tidak akan mampu menyelesaikan masalah yang berkaitan dengan matematika. Hal ini tentu saja tidak dapat dibiarkan berlarut-larut dan harus segera diatasi dengan cara mengganti model pembelajaran konvensional dengan model-model pembelajaran yang jauh lebih inovatif, kreatif, efektif, berpusat pada siswa, dan menggembirakan siswa.salah satunya dengan menggunakan metode cooperative learning.

Suprijono, Agus (2010:54) "Model pembelajaran kooperatif adalah konsep yang lebih luas meliputi semua jenis kerja kelompok termasuk bentuk-bentuk yang dipimpin oleh guru atau diarahkan oleh guru". Slavin (dalam Isjoni, 2011:15) "In cooperative learning methods, students work together in four member teams to master material initially presented by the teacher". Ini berarti bahwa cooperative learning atau 
pembelajaran kooperatif adalah suatu model pembelajaran dimana sistem belajar dan bekerja kelompok-kelompok kecil berjumlah 4-6 orang secara kolaboratif sehingga dapat merangsang peserta didik lebih bergairah dalam belajar.

Menurut Zaini (2008) memberikan pengertian jigsaw sebagai strategi pembelajaran yang digunakan jika materi dapat dibagi menjadi beberapa bagian dan dalam menyempaikannya tidak mengharuskan sistematis. Sehingga dapat dikatakan bahwa kelebihan strategi ini ialah dapat melibatkan para siswa untuk belajar dan smengajarkan kepada siswa lain. Sudrajat (2008) memberikan pengertian bahwa tipe pembelajaran kooperatif jigsaw adalah pembelajaran yang dilakukan dengan berkelompok dan mampu mengajarkan materi tersebut kepada kelompok lainya. Menurut Wina Sanjaya (2011: 243) kelebihan pembelajaran kooperatif tipe jigsaw adalah sebagai berikut:Siswa diajarkan bagaimana bekerjasama dalam kelompok, siswa yang lemah dapat terbantu dalam menyelesaikan masalah, menerapkan bimbingan sesama teman, rasa harga diri siswa yang lebih tinggi, pemahaman materi lebih mendalam, dan meningkatkan motivasi belajar

Kekurangan pembelajaran kooperatif tipe jigsaw menurut Shoimin (2014: 93-94) adalah sebagai berikut : guru membutuhkan keterampilan lebih dikarenakan setiap kelompok membutuhkan penanganan yang berbeda, dan membutuhkan waktu yang lebih lama

Dari uraian di atas diketahui bahwa Model Pembelajaran Jigsaw merupakan model pembelajaran yang sangat menarik, sebab model pembelajaran ini menguraikan cara-cara baru yang memudahkan proses belajar. Dalam pelaksanaannya Model Pembelajaran Jigsaw diharapkan akan mampu menarik perhatian siswa, menjadikan siswa selalu aktif dalam pembelajaran yang secara tidak langsung akan membangun interaksi yang multi arah, menyenangkan dan bermakna bagi siswa, serta memunculkan kreativitas dari dalam diri siswa, sehingga guru hanya berfungsi sebagai fasilitator saja dan bukan sebagai pusat pembelajaran.

Penerapan model ini diharapkan dapat meningkatkan hasil belajar siswa pada Mata Pelajaran Matematika pada siswa kelas V SDN 2 Sedayu. Oleh karena itu, berdasarkan latar belakang tersebut di atas, peneliti ingin melakukan penelitian dengan judul "Penggunaan Model Pembelajaran Jigsaw untuk Meningkatkan Hasil belajar Matematika pada Siswa Kelas V SDN 2 Sedayu Tahun Pelajaran 2018/2019".

Bertolak dari latar belakang masalah di atas, maka permasalahan dalam penelitian ini dapat dirumuskan sebagai berikut : Apakah penggunaan Model Pembelajaran Kuantum dapat meningkatkan hasil belajar siswa kelas V SDN 2 Sedayu tahun pelajaran 2018/2019?

Kendala-kendala apa sajakah yang menghambat penggunaan Model Pembelajaran Jigsaw dalam upaya meningkatkan hasil belajar matematika pada siswa kelas V SDN 2 Sedayu tahun pelajaran 2018/2019?

Berdasarkan permasalahan yang telah dirumuskan, tujuan yang hendak dicapai dalam penelitian ini adalah : Untuk meningkatkan hasil belajar matematika melalui penggunaan Model Jigsaw pada siswa kelas V SDN 2 Sedayu tahun pelajaran 2018/2019. Untuk mendeskripsikan cara mengatasi kendala-kendala yang menghambat penggunaan Model Pembelajaran Jigsaw dalam upaya meningkatkan hasil belajar matematika pada siswa kelas V SDN 2 Sedayu tahun pelajaran 2018/2019.

\section{METODE}

Jenis penelitan yang dilakukan oleh penulis adalah Penelitian Tindakan Kelas (PTK). Menurut Kurt Lewin dalam Kunandar (2011:42) penelitian tindakan kelas ini terdiri dari empat tahapan dasar yaitu perencanaan (planning), pelaksanaan (acting), pengamatan (observing) dan refleksi (reflecting). Analisis penelitian ini adalah analisis deskriptif kuantitafif. Model pembelajaran yang digunakan yaitu model kooperatif 
learning. Menurut Buchari Alma (2009:80) Cooperative berarti bekerja sama sedangkan learning berarti belajar, jadi belajar melalui kegiatan bersama. Metode yang digunakan adalah Jigsaw. Lie (dalam Rusman, 2012:218) mengemukakan bahwa model pembelajaran tipe jigsaw merupakan model belajar kooperatif dengan cara siswa belajar dalam kelompok kecil yang terdiri dari $4-6$ orang secara heterogen dimana siswa belajar secara bekerjasama yang saling berkertergantungan positif dan bertanggungjawab secara mandiri. Penelitian ini dilakukan pada siswa kelas V SDN 2 Sedayu tahun pelajaran 2018/2019. Dilaksanakan dalam 2 siklus dengan masing masing siklus ada 2 kali pertemuan. Siklus I dilaksankan pada tanggal 27 dan 28 Agustus 2018 sedangkan siklus II dilaksanakan pada tanggal 5 dan 6 September 2018. Teknik pengumpulan data pada penelitian ini adalah dengan Teknik tes dan observasi. S. Margono (2009:158) Observasi diartikan sebagai pengalaman dan pencatatan secara sistematik terhadap gejala yang tampak pada objek penelitian. Sedangkan Teknik tes melalui pretest dan postest.

\section{HASIL DAN PEMBAHASAN}

Sebelum penelitian dilaksanakan, peneliti telah melakukan kegiatan observasi awal terhadap proses pembelajaran matematika pada siswa kelas V SDN 2 Sedayu tahun pelajaran 2018/2019. Kegiatan observasi dan studi dokumentasi ini dilakukan dengan tujuan untuk mengumpulkan data yang diperlukan dalam penelitian dan untuk mengetahui keadaan nyata yang ada di lapangan sebagai berikut:

Tabel 1. Data Hasil Nilai Prasiklus

\begin{tabular}{cccc}
\hline Interval Nilai & Frekuensi & Persentase & Ketuntasan \\
\hline $0-10$ & 1 & $10 \%$ & $\mathrm{BT}$ \\
$11-20$ & 2 & $20 \%$ & $\mathrm{BT}$ \\
$21-30$ & 1 & $10 \%$ & $\mathrm{BT}$ \\
$31-40$ & 0 & $0 \%$ & - \\
$41-50$ & 1 & $10 \%$ & $\mathrm{BT}$ \\
$51-60$ & 2 & $20 \%$ & $\mathrm{BT}$ \\
$61-70$ & 0 & $0 \%$ & - \\
$71-80$ & 1 & $10 \%$ & $\mathrm{~T}$ \\
$81-90$ & 1 & $10 \%$ & $\mathrm{~T}$ \\
$91-100$ & 1 & $10 \%$ & $\mathrm{~T}$ \\
\hline Jumlah & $\mathbf{1 0}$ & $\mathbf{1 0 0} \%$ & \\
\hline
\end{tabular}

Berdasarkan tabel 1 di atas dapat disimpulkan bahwa pada tindakan prasiklus nilai siswa dalam materi volume bangun ruang yang memenuhi KKM $\geq 71$ hanyalah $30 \%$ atau hanya 3 siswa dari 10 siswa. Hal ini dikategorikan rendah karena belum memenuhi kriteria ketuntasan yang ditetapkan yaitu mencapai $80 \%$. Oleh Rendahnya hasil belajar atau ketidaktuntasan tersebut disebabkan oleh beberapa faktor, diantaranya: (1) Materi Mata Pelajaran Matematika sangat sulit dimengerti karena sifatnya yang abstrak, sehingga membuat siswa merasa jenuh dan menganggapnya sebagai momok; (2) Guru dalam melakukan pembelajaran masih bersifat konvensional. Oleh karena itu, diperlukan suatu model pembelajaran yang tepat untuk mengatasi permasalahan tersebut yaitu dengan penerapan Model Pembelajaran Jigsaw. Menurut Elliot Aronson (dalam Trianto: 2010) metode Jigsaw langkahnya sebagai berikut: kelas dibagi menjadi beberapa tim yang anggotanya terdiri dari 5 atau 6 siswa dengan karakteristik yang heterogen, bahan akademik disajikan kepada siswa dalam bentuk teks, dan setiap siswa bertanggung jawab untuk mempelajari suatu bagian dari bahan akademik tersebut, para anggota dari beberapa tim yang berbeda memiliki tanggung jawab untuk mempelajari suatu bagian akademik yang sama dan 
selanjutnya berkumpul untuk saling membantu mengkaji bagian bahan tersebut, selanjutnya para siswa yang berada dalam kelompok pakar (ahli) kembali ke kelompok semula (home teams) untuk mengajar anggota lain mengenai materi yang telah dipelajari dalam kelompok pakar (ahli), setelah diadakan pertemuan dan diskusi dalam "home teams", para siswa dievaluasi secara individual mengenai bahan yang telah dipelajari.

Melalui penggunaan Model Pembelajaran Jigsaw diharapkan hasil belajar siswa kelas $\mathrm{V}$ akan mengalami peningkatan sehingga target ketuntasan belajar siswa dapat tercapai.

Hasil pelaksanaan Siklus 1

Pada pelaksanaan siklus I dilaksanakan dalam 2 pertemuan. Setiap akhir pertemuan akan diadakan post test atau evaluasi untuk mengetahui ketercapaian siswa dalam mempelajari kompetensi. Data yang diperoleh melalui tes evaluasi dan observasi dikumpulkan kemudian dianalisis. Berdasarkan hasil tes evaluasi dan observasi yang dilakukan selama proses pelaksanaan tindakan, peneliti melakukan refleksi dengan cara mengumpulkan data dari pertemuan 1 dan 2 selanjutnya dibuat rata-rata, setelah dirata-rata kemudian dibandingkan dengan indikator kinerja yang telah ditetapkan. Indikator kinerja siklus I yaitu aspek kognitif siswa yang dinyatakan tuntas sebanyak 8 siswa atau $80 \%$. Adapun data yang diperoleh adalah dapat disajikan seperti pada tabel 2 dan grafik 1 berikut ini :

Tabel 2. Data Hasil Nilai Siklus 1

\begin{tabular}{cccc}
\hline Interval Nilai & Frekuensi & Persentase & Ketuntasan \\
\hline $0-10$ & 0 & $0 \%$ & - \\
$11-20$ & 0 & $0 \%$ & - \\
$21-30$ & 0 & $0 \%$ & - \\
$31-40$ & 0 & $0 \%$ & - \\
$41-50$ & 0 & $0 \%$ & - \\
$51-60$ & 1 & $10 \%$ & $\mathrm{BT}$ \\
$61-70$ & 2 & $20 \%$ & $\mathrm{BT}$ \\
$71-80$ & 3 & $30 \%$ & $\mathrm{~T}$ \\
$81-90$ & 3 & $30 \%$ & $\mathrm{~T}$ \\
$91-100$ & 1 & $10 \%$ & $\mathrm{~T}$ \\
\hline Jumlah & $\mathbf{1 0}$ & $\mathbf{1 0 0} \%$ &
\end{tabular}




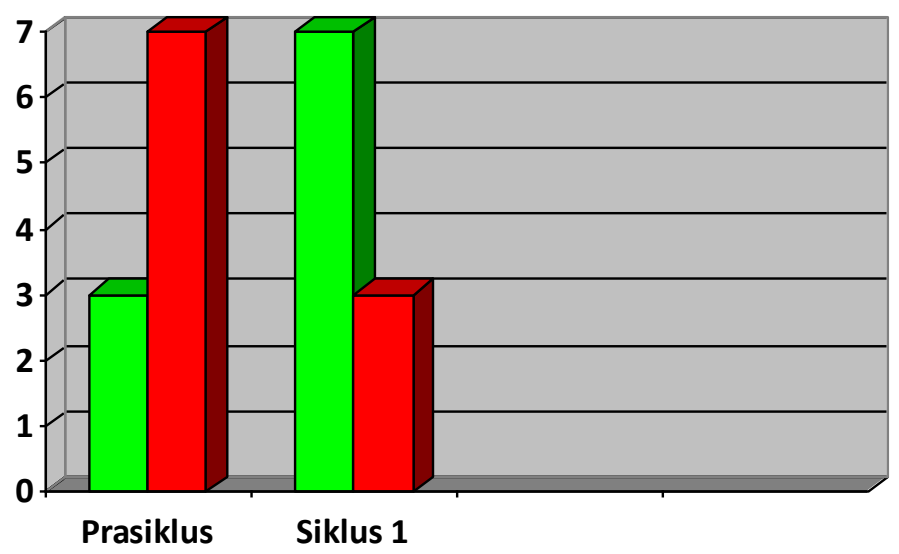

$\square$ Tuntas
$\square$ Belum Tuntas

\section{Gambar 1. Grafik Tingkat Ketuntasan siswa}

Berdasarkan data di atas di peroleh siswa yang sudah mencapai $\mathrm{KKM} \geq 71$ ada $70 \%$ atau 7 siswa dari 10 siswa dan siswa yang belum mencapai KKM $\geq 71$ ada $30 \%$. Dari data hasil penelitian siklus I di atas, maka peneliti mengulas secara cermat bahwa dilihat dari nilai evaluasi yang diperoleh siswa dengan menggunakan model pembelajaran jigsaw sudah cukup berhasil. Dalam artian, penelitian ini menunjukan bahwa terjadi peningkatan terhadap hasil belajar matematika siswa kelas V SDN 2 Sedayu jika dibandingkan dengan hasil prasiklus. Namun, peningkatan tersebut masih belum memenuhi indikator ketercapaian siklus I, yaitu $80 \%$. Oleh karena itu, peneliti memutuskan untuk melanjutkan penelitian ke siklus berikutnya, yaitu siklus II.

Hasil pelaksanaan siklus 2

Berdasarkan hasil evaluasi pada pelaksanaan tindakan siklus I diketahui bahwa penerapan Model Pembelajaran Jigsaw dapat meningkatkan hasil belajar matematika pada siswa kelas $\mathrm{V}$. Akan tetapi, peningkatan tersebut masih belum memenuhi target ketercapaian. Oleh karena itu, setelah disusun rencana penelitian tindakan kelas dengan lebih matang serta dilaksankan dengan penuh tanggungjawab diperoleh hasil sebagai berikut:

Tabel 3. Data Hasil Nilai Siklus 2

\begin{tabular}{cccc}
\hline Interval Nilai & Frekuensi & Persentase & Ketuntasan \\
\hline $0-10$ & 0 & $0 \%$ & - \\
$11-20$ & 0 & $0 \%$ & - \\
$21-30$ & 0 & $0 \%$ & - \\
$31-40$ & 0 & $0 \%$ & - \\
$41-50$ & 0 & $0 \%$ & - \\
$51-60$ & 1 & $10 \%$ & $\mathrm{BT}$ \\
$61-70$ & 0 & $0 \%$ & - \\
$71-80$ & 2 & $20 \%$ & $\mathrm{~T}$ \\
$81-90$ & 4 & $40 \%$ & $\mathrm{~T}$ \\
$91-100$ & 3 & $30 \%$ & \\
\hline Jumlah & $\mathbf{1 0}$ & $\mathbf{1 0 0} \%$ &
\end{tabular}




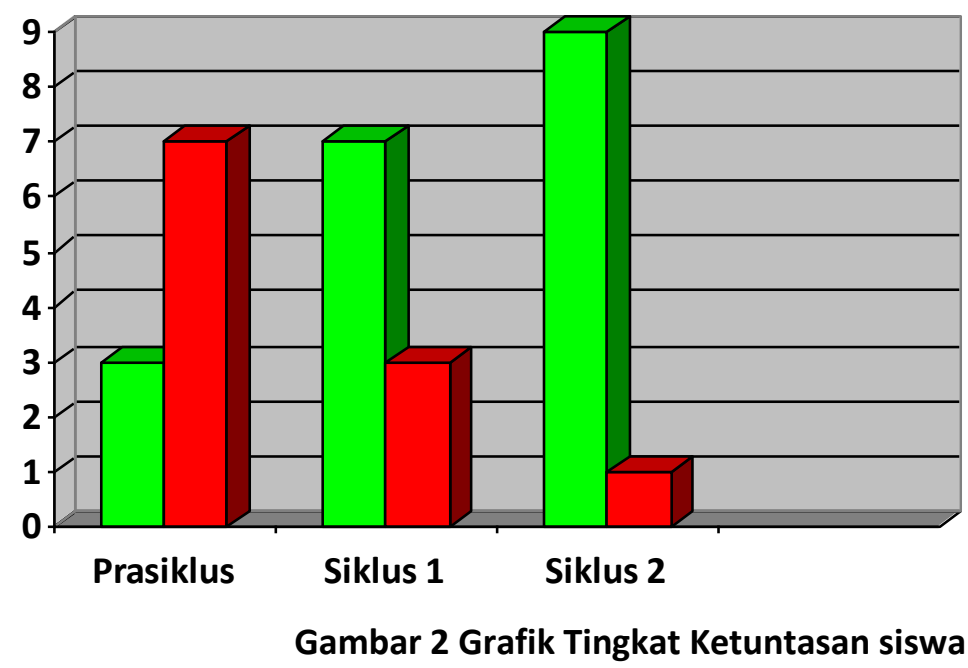

$\square$ Tuntas
$\square$ Belum Tuntas

Berdasarkan pelaksanaan siklus 2 diperoleh siswa yang mencapai ketuntasan minimal sudah mencapai $90 \%$ dan hasil ini sudah memenuhi kriteria ketuntasan yang di tetapkan yaitu $80 \%$. Dari hasil penelitian siklus 2, maka peneliti mengulas secara cermat bahwa dilihat dari hasil pengamatan dan nilai evaluasi yang diperoleh siswa dengan menggunakan model pembelajaran jigsaw sudah berhasil. Hal ini menunjukan bahwa terjadi peningkatan hasil belajar matematika siswa kelas V SDN 2 Sedayu dan peningkatan tersebut sudah memenuhi indikator ketercapaian siklus 2 yaitu $80 \%$. Kemampuan siswa kelas V SDN 2 Sedayu dalam pembelajaran matematika dengan model jigsaw dari siklus I sampai dengan siklus 2 selalu mengalami peningkatan dan berhasil mencapai target indikator yang telah ditentukan, oleh karena itu, peneliti memutuskan untuk menghentikan penelitian pada siklus 2 .

Dari 2 siklus yang sudah dilaksanakan dalam 4 pertemuan ini dapat dipastikan bahwa model pembelajaran Jigsaw dapat meningkatkan hasil belajar matematika siswa SDN 2 Sedayu tahun pelajaran 2018/2019.

\section{SIMPULAN}

Berdasarkan hasil penelitian tindakan kelas yang dilakukan dalam dua siklus selama empat kali pertemuan dapat dibuat kesimpulan sebagai berikut: aspek ketuntasan kognitif meningkat dari kegiatan prasiklus 30\% atau sebanyak 3 siswa, siklus II berubah menjadi 70\% (7 siswa) dan siklus II mencapai 90\% (9 siswa). Dari data-data hasil penelitian tersebut, maka terbukti bahwa Model Pembelajaran Jigsaw dapat meningkatkan hasil belajar matematika siswa kelas V SDN 2 Sedayu tahun pelajaran 2018/2019.

\section{Implikasi}

Berdasarkan hasil dari penelitian yang dilakukan dalam dua siklus di atas terbukti bahwa penggunaan Model Pembelajaran Jigsaw dapat meningkatkan hasil belajar matematika siswa SDN 2 Sedayu. Sehubungan dengan penelitian ini maka dapat dikemukakan implikasi hasil penelitian sebagai berikut: dari hasil penelitian menunjukkan bahwa penggunaan Model Pembelajaran Jigsaw dapat dijadikan alternatif bagi guru dalam upaya meningkatkan hasil belajar matematika, sehingga penelitian ini juga dapat digunakan sebagai bahan referensi penelitian selanjutnya yang sejenis ( Implikasi Teoritis). Kemudian hasil penelitian ini dapat digunakan guru untuk menentukan model pembelajaran yang tepat sehingga dapat meningkatkan 
kualitas proses belajar mengajar sesuai dengan tujuan pembelajaran yang akan dicapai (Implikasi Praktis).

\section{DAFTAR PUSTAKA}

Buchari, Alma, et, all. 2009. Guru Profesional Mengenal Metode dan Terampil Mengajar. Bandung : Alfabeta.

Hisyam Zaini. 2008. Srategi pembelajaran aktif. Yogyakarta: Insan Mandiri.

Isjoni. 2011. Cooperative Learning Efektivitas Pembelajaran Kelompok. Bandung: ALFABETA

Kunandar. 2011. Langkah Mudah Penelitian Tindakan Kelas Sebagai Pengembang Profesi Guru. Jakarta: PT Raja Grafindo Persada

Margono, S. 2009. Metodologi Penelitian Pendidikan Komponen MKDK. Jakarta: PT. Rineka Cipta

Muhsetyo, G. 2009. Pembelajaran Matematika SD. Jakarta: Universitas Terbuka

Rusman. 2012. Model-model Pembelajaran (Mengembangkan Profesionalisme Guru Edisi Kedua). Jakarta: Raja Grafindo Persada.

Sanjaya, Wina.2011. Strategi Pembelajaran Berorientasi Standar Proses Pendidikan. Jakarta: Kencana.

Shoimin, Aris. 2014. 68 Model Pembelajaran INOVATIF dalam Kurikulum 2013. Yogyakarta: AR-RUZZ MEDIA.

Sudrajad, Akhmad. 2008. Pengertian Pendekatan, Strategi, Metode, Teknik dan Model Pembelajaran. Bandung : Sinar Baru Algensindo.

Sukandi, Ujang (dalam Kholik). 2011. Pembelajaran Konvensional. Surakarta: Panitia Sertifikasi.

Suprijono, Agus. 2010. Cooperative Learning Teori \& Aplikasi Paikem. Yogyakarta: Pustaka Pelajar.

Susanto, Ahmad. 2015. Teori Belajar Dan Pembelajaran Disekolah Dasar. Jakarta: Prenada Media.

Trianto, 2010. Mendesain Model Pembelajaran Inovatif Progresif Konsep, Landasan Dan Implementasinya pada Kurikulum Tingkat Satuan Pendidikan (KTSP). Jakarta: Kencana 